Review Article

\title{
Establishment And Enforcement of Sovereignty in Hoang Sa And Truong Sa Areas of The State of Vietnam From After The Patenotre Convention (1884) to the Event of April 30, 1975
}

\author{
Nguyen Ba Dien* \\ VNU School of Law, 144 Xuan Thuy, Cau Giay, Hanoi, Vietnam
}

Received 13 August 2020

Revised 11 September 2020; Accepted 29 September 2020

\begin{abstract}
The article summarizes the establishment and implementation of sovereignty over the two areas (archipelagoes) of Hoang Sa and Truong Sa by the State of Vietnam through the operation of the French colonial government - representing Vietnam simultaneously with activities the sovereignty exercise of the dynasties and government of Vietnam in important historical period: from the Patonot Treaty to April 30, 1975. The article affirms: the state of Vietnam, through during the periods, the two regions of islands (archipelagoes), Hoang Sa and Truong Sa, were actually, publicly and continuously occupied. Hoang Sa and Truong Sa have never been in Chinese territory. The Chinese occupation of the Hoang Sa and Truong Sa islands of Vietnam is a serious violation of international law, constituting an international crime, is worthless.
\end{abstract}

Keywords: State of Vietnam, sovereignty enforcement, France, China, Paracel Islands, Truong Sa.

\footnotetext{
${ }^{*}$ Corresponding author.

E-mail address: nbadien@yahoo.com

https://doi.org/10.25073/2588-1167/vnuls.4313
} 


\title{
Việc xác lập và thực thi chủ quyền trên hai vùng đảo Hoàng Sa và Trường Sa của nhà nước Việt Nam giai đoạn từ sau hiệp ước Pa-tơ-nôt (1884) đến sự kiện 30 tháng 4 năm 1975
}

\author{
Nguyễn Bá Diến* \\ Khoa Luật, Đại học Quốc gia Hà Nội, 144 Xuân Thủy, Cầu Giấy, Hà Nội, Việt Nam \\ Nhận ngày 13 tháng 8 năm 2020 \\ Chỉnh sửa ngày 11 tháng 9 năm 2020; Chấp nhận đăng ngày 29 tháng 9 năm 2020
}

\begin{abstract}
Tóm tắt: Bài viết khái quát việc xác lập và thực thi chủ quyền trên hai vùng đảo Hoàng Sa và Trường Sa của Nhà nước Việt Nam thông qua hoạt động của chính quyền thực dân Pháp-đại diện cho Việt Nam, đồng thời với các hoạt động thực thi chủ quyền của các triều đại và chính quyền Việt Nam trong giai đoạn lịch sử quan trọng: từ Hiệp ước Pa-tơ-nốt cho đến ngày 30 tháng 4 năm 1975. Bài viết khẳng định rằng nhà nước Việt Nam, qua các thời kỳ, đã khai phá , chiếm hữu thật sự, công khai và liên tục hai vùng đảo ( quần đảo) Hoàng $\mathrm{Sa}$ và Trường Sa. Hoàng Sa và Trường Sa chưa bao giờ thuộc lãnh thổ của Trung Quốc. Việc chiếm đóng của Trung Quốc ở vùng đảo Hoàng Sa và Trường Sa của Việt Nam là hành vi vi phạm pháp luật quốc tế nghiêm trọng, là cấu thành tội ác quốc tế, là vô giá trị.

Tù khóa: Nhà nước Việt Nam, thực thi chủ quyền, nước Pháp, Trung Quốc, vùng đảo Hoàng Sa, Trường Sa
\end{abstract}

Biển Đông là không gian sinh tồn của dân tộc Việt Nam. Đặc biệt, hai vùng đảo (quần đảo) Hoàng $\mathrm{Sa}$ và Trường $\mathrm{Sa}$ có ý nghĩa địachiến lược về mọi mặt, nhất là về quốc phòng và an ninh đối với Việt Nam. Việt Nam là quốc gia đầu tiên khai phá, chiếm hữu, xác lập và thực thi chủ quyền trên hai vùng đảo Hoàng $\mathrm{Sa}$ và Trường Sa một cách hòa bình, công khai, liên tục và hữu hiệu, phù hợp với luật pháp và tập quán quốc tế. Với một hệ thống bằng chứng lịch sử-khoa học đồ sộ và với những lập luận trung thực, khách quan và toàn diện, Việt Nam là quốc gia duy nhất có chủ quyền trên hai vùng đảo Hoàng $\mathrm{Sa}$ và Trường $\mathrm{Sa}$. Bài viết chỉ xin trình bày vắn tắt một số minh chứng lịch sử pháp lý về chủ quyền không thể tranh biện trên hai vùng đảo Hoàng $S a$ và Trường $S a$ của Việt

\footnotetext{
* Tác giả liên hệ.

Địa chỉ email: nbadien@yahoo.com
}

https://doi.org/10.25073/2588-1167/vnuls.4313
Nam, đã và đang bị Trung Quốc dùng vũ lực xâm chiếm phi pháp trong những năm qua.

\section{Việc nước Pháp nhân danh Nhà nước Việt Nam tiếp tục thực hiện chủ quyền đối với hai vùng đảo Hoàng $S a$ và Trường $S a$}

Từ khi ký với triều đình nhà Nguyễn Hiệp ước ngày 06/6/1884, Pháp đại diện quyền lợi của Việt Nam trong quan hệ đối ngoại và đồng thời việc bảo vệ chủ quyền và toàn vẹn lãnh thổ của Việt Nam. Trên cơ sở luật pháp quốc tế, trong khuôn khổ sự cam kết của Hiệp định Paternotre ngày 06/6/1884, Pháp đại diện cho Việt Nam [1], tiếp tục thực hiện chủ quyền của Việt Nam đối với hai vùng đảo Hoàng Sa và Trường Sa. thể [2]:

Sau đây là một số minh chứng chứng cụ 
Các pháo hạm của Pháp thường xuyên tiến hành tuần tiễu trong vùng Biển Đông kể cả vùng Hoàng $\mathrm{Sa}$ và Trường $\mathrm{Sa}$. Không những vậy, đối với vùng đảo Hoàng $\mathrm{Sa}$, chính quyền bảo hộ của Pháp đã thay mặt An Nam thực thi chủ quyền một cách hữu hiệu và liên tục bằng nhiều hoạt động quản lý nhà nước công khai.

Theo báo La Nature số 2916 ra ngày 1/11/1933, năm 1899, Toàn quyền Đông Dương Paul Doumer đề nghị với Paris cho xây tại đảo Hoàng Sa (Pattle) trong vùng đảo Hoàng Sa một hải đăng để hướng dẫn các tàu biển qua lại vùng này, nhưng kế hoạch không thực hiện được vì thiếu kinh phí. Đối với sự kiện này, tờ La Nature nhận xét: "Chính phủ Pháp đã thiết lập sự đô hộ của họ đối với An Nam mà những hòn đảo này (vùng đảo Hoàng $\mathrm{Sa}$ ) thuộc lãnh thổ của $\mathrm{An}$ Nam, nên Pháp có quyền sở hữu và trách nhiệm coi sóc đối với lãnh thổ mới này" [3]

Trước các chỉ trích của dư luận cũng như thực tế diễn biến phức tạp trên Biển Đông, từ đầu thế kỷ $\mathrm{XX}$, Pháp đã bắt đầu có những động thái tích cực hơn trong việc khẳng định chủ quyền tại hai vùng đảo Hoàng $\mathrm{Sa}$ và Trường $\mathrm{Sa}$. Bên cạnh việc gìn giữ an ninh trên Biển Đông, các năm 1917-1918 trong báo cáo của chính quyền Pháp tại Đông Dương có đề cập đến việc lắp đặt đài radio TSF, trạm quan sát khí tượng, hải đăng trên vùng đảo Hoàng $\mathrm{Sa}$ và Trường $\mathrm{Sa}$ [3]. Từ năm 1920, Pháp thực hiện việc kiểm soát trên biển và kiểm soát hải quan đối với vùng đảo Hoàng $\mathrm{Sa}$ [4]

Từ năm 1925 đến năm 1927, việc nghiên cứu khoa học về vùng đảo Hoàng Sa do một phái đoàn đứng đầu là Tiến sỹ A.Krempf, Giám đốc Viện Hải Dương học lãnh đạo thưc hiện trên tàu lưới kéo De Lanessan ra khảo sát ở quần về hải dương học [4]. Ngoài A.Krempf, giám đốc Viện hải dương học, còn có các nhà khoa học khác như Delacour, Jabouille...nghiên cứu về địa chất, về sinh vật... Tháng 7 năm 1927, tàu de Lanessan của Pháp tiến hành một cuộc khảo sát khoa học trên vùng đảo Trường Sa [4]. Các cuộc khảo sát khoa học đã đưa tới kết luận vùng Hoàng $\mathrm{Sa}$ và Trường $\mathrm{Sa}$ là sự nhô lền của một thềm lục địa liên tục nhờ các địa tầng dưới biển kéo dài dãy Trường Sơn từ đèo Hải Vân ra biển Đông. Nếu nước biển rút xuống khoảng $600-700 \mathrm{~m}$ thì Hoàng $\mathrm{Sa}$ và Trường Sa sẽ gắn với bờ biển Việt Nam thành một dải đất liền thống nhất [4].

Ngày 3/3/1925, Thượng thư Bộ Binh của Triều đình Huế Thân Trọng Huề lại khẳng định Hoàng Sa là lãnh thổ Việt Nam

Ngày $8 / 3 / 1925$, Toàn quyền Đông Dương tuyên bố khẳng định vùng đảo Hoàng $\mathrm{Sa}$ và Trường Sa là lãnh thổ của An Nam thuộc Pháp [4].

Năm 1927, Tổng lãnh sự Nhật Bản , ông Kurosawa, yêu cầu chính quyền Pháp ở Đông Dương cung cấp các thông tin về quy chế lãnh thổ của vùng đảo Trường $\mathrm{Sa}$

Tháng 11/1928, Thống đốc Nam Kỳ cấp giấy phép nghiên cứu mỏ ở vùng đảo Hoàng $\mathrm{Sa}$ cho Công ty Phosphat Bắc Kỳ Mới. Trong thư ngày 20/3/1930, Toàn quyền Đông Dương gởi cho Bộ trưởng Bộ Thuộc địa Pháp xác nhận: "Cần thừa nhận lợi ích nước Pháp có thể có trong việc nhân danh An Nam, đòi chủ quyền đối với vùng đảo Hoàng Sa" [3]. Ngày 13/4/ 1930, Roàn quyền Đông Dương gửi thông báo hạm la Malicieuse đến vùng đảo Trường Sa và treo quốc kỳ Pháp trên đảo. Từ 13/4/1930 đến 12/4/1933, chính phủ Pháp đã cử các đơn vị hải quân lần lượt ra tiếp quản các đảo chính trong vùng đảo Trường $\mathrm{Sa}$ : Trường $\mathrm{Sa}$ (Spratley) ngày 13/4/1930, An Bang (Caye d' Ambonine) ngày 7/4/1933, Itu Aba ngày 10/4/1933, nhóm Song Tử (group dé deux iles) ${ }^{1}$ ngày 10/4/1933, Loại Ta, Thị Tứ ngày 12/4/1933 [5].

Ngày 4/12/1931 và ngày 29/4/1932, Pháp phản kháng Trung Quốc về việc chính quyền Quảng Đông lúc đó có ý định cho đầu thầu khai thác phosphat trên vùng đảo Hoàng $\mathrm{Sa}$. Kháng nghị của Chính phủ Pháp nêu rõ các danh nghĩa lịch sử và các bằng chứng về sự chiếm hữu của An Nam, sau đó là của Pháp. Cùng năm này (năm 1932), Pháp đề nghị đưa vụ tranh chấp này ra các tòa án quốc tế và Trung Quốc đã từ chối đề nghị này [6].

Ngày 15 tháng 6 năm 1932, Toàn quyền Đông Dương ra Nghị định số $156 / \mathrm{SC}$, thiết lập đon vị hành chính ở Hoàng $\mathrm{Sa}$ (délégation

\footnotetext{
${ }^{1}$ Tức là đảo Song Tử Tây và đảo Song Tử Đông.
} 
administrative des Paracels). Ngày 13/4/1933, một hạm đội của hải quân Pháp ở Viễn Đông dưới sự chỉ huy của trung tá hải quân De Lattre rời Sài Gòn ra vùng đảo Trường $S a$ thực hiện đầy đủ các nghi thức truyền thống theo đúng tập quán quốc tế về việc chiếm hữu lãnh thổ tại đây. Mỗi đảo nhận một văn bản, được đóng kín vào một cái chai rồi được gắn trong một trụ xi măng xây trên mỗi đảo, kéo cờ và thổi kèn trên từng hòn đảo [6].

Ngày 14 tháng 3 năm 1933, một hạm đội của hải quân Pháp ở Viễn Đông gồm tàu Malicieuse, tàu pháo Arlete và hai tàu thuỷ văn Astrobale và de Lanessan dưới sự chỉ huy của trung tá hải quân De Lattre rời Sài Gòn ra vùng đảo Trường $\mathrm{Sa}$ đến đảo Trường Sa và hàng loạt địa điểm khác như đá Chữ Thập, cụm rạn Luân Đôn, bãi san hô Tizard, bãi san hô Loại Ta, cụm rạn Thị Tứ và rạn Nguy Hiểm Phía Bắc [7]. Pháp đã cho thực hiện đầy đủ các nghi thức truyền thống theo đúng tập quán quốc tế về việc chiếm hữu lãnh thổ tại đây. Tại từng địa điểm đi qua, người Pháp đã tổ chức nghi lễ̂ chiếm hữu các đảo chính thuộc nơi đó. Mỗi đảo nhận một văn bản, được đóng kín vào một cái chai rồi được gắn trong một trụ xi măng xây trên mỗi đảo, kéo cờ và thổi kèn trên từng hòn đảo [6].

Theo Nghị định ngày 26 tháng 7 năm 1933, Chính phủ Pháp công bố việc chiếm hữu của Pháp đối với vùng đảo Trường $\mathrm{Sa}$, kèm theo danh sách liệt kê tên các đảo đã chiếm hữu cùng tọa độ [6], bao gồm: 1) Đảo Spratly-Đảo Trường Sa (chiếm ngày 13 tháng 4 năm 1930), 2) Đảo Caye-d'Amboine- Đảo An Bang (7 tháng 4 năm 1933), 3) Tiểu đảo Itu-Aba - Đảo Ba Bình (10 tháng 4 năm 1933), 4) Nhóm Hai Đảo, tức Song Tử Đông và Song Tử Tây (Groupe de Deux-îles, 10 tháng 4 năm 1933), 5) Đảo Loaito- Đảo Loại Ta (11 tháng 4 năm 1933), 6) Đảo Thi-Tu- Đảo Thị Tứ (12 tháng 4 năm 1933) và các đảo nhỏ phụ thuộc từng đảo này $[8]$.

Từ ngày 24 tháng 7 đến ngày 25 tháng 9 năm 1933, Pháp lần lượt thông báo cho các quốc gia biết về hành động chiếm hữu của Pháp ở vùng đảoTrường Sa. Nhật đã phản kháng nhưng Pháp đã bác bỏ sự phản kháng đó của Nhật. Theo Bạch thư (Sách trắng) của Bộ Ngoại giao Việt Nam Cộng hòa, thì ngoại trừ Nhật Bản, tất cả các nước được thông báo đều không có lời phản đối Pháp; Trung Hoa Dân Quốc, Hà Lan (đang kiểm soát Indonesia) và Hoa Kỳ cũng đều giữ im lặng [7].

Ngày 21 tháng 12 năm 1933, Thống đốc Nam KỳJean-Félix Krautheimer kí Nghị định số 4702-CP sáp nhập số đảo trên và "các đảo phụ thuộc" vào địa phận tỉnh Bà Rịa thuộc Liên bang Đông Dương [9]. Sáu năm sau, Thứ trưởng Ngoại giao Anh Quốc là Butter tuyên bố rằng Pháp đã thực thi đầy đủ chủ quyền trên vùng đảo Hoàng $\mathrm{Sa}$ và Trường $\mathrm{Sa}$ [7].

Thông báo của Bộ Ngoại giao pháp về việc chiếm cứ vùng đảo Trường Sa đăng trong Công báo của Chính phủ Pháp số 173 ngày 26/7/1933 trang 7839.

Ngày 21/12/1933, Thống đốc Nam Kỳ M.j.Krautheimer ký Nghị định số 4762 sát nhập các đảo Trường $\mathrm{Sa}$, An Bang, Itu Aba, nhóm Song Tử, Loại Ta và Thị Tứ vào địa phận tỉnh Bà Rịa ${ }^{2}$.

Năm 1937, kỹ sư trưởng công chính Pháp Ganthier nhân danh chính quyền thuộc địa Pháp ra vùng đảo Hoàng Sa thực hiện nhiệm vụ nghiên cứu khả năng xây dựng đèn biển, lập bãi thủy phi cơ.

Tháng 2/1937, tuần dương hạm Lamotle Piquet do Phó đô đốc Istava chỉ huy thăm vùng đảo Hoàng $\mathrm{Sa}$.

Trước năm 1938, vùng đảo Hoàng Sa thuộc phủ Quảng Nghĩa, tỉnh Nam Ngãi. Ngày 30 tháng 3 năm 1938, Hoàng đế Bảo Đại ký đạo du số 10 chuyển Hoàng Sa về tỉnh Thù̃a Thiên. ${ }^{3}$

Theo Nghị định ngày 15 tháng 6 năm 1938, Toàn quyền Đông Dương Jules Brévié thành lập một đại lý hành chính trên vùng đảo Hoàng Sa. Ngày 5/5/1939, Toàn quyền Đông Dương Jules Brévié ký Nghị định số 3282 sửa đổi Nghị định ngày $5 / 6 / 1938$ nói trên và chia khu vực này thành hai nhóm [6]: Nhóm Nguyệt Thiềm (De'le'gation du Croissant et de'pedances) và Nhóm An Vĩnh (De'le'gation de 1, Amphitrite Croissant et de'pedances). Trụ sở của hai đơn vị

\footnotetext{
${ }^{2}$ Nay thuộc tỉnh Khánh Hòa.

${ }^{3}$ Nay thuộc thành phố Đà Nẵng.
} 
hành chính này được đặt tại đảo Hoàng Sa (Pattle Island) và đảo Phú Lâm (Woody Island). Một tấm bia được dựng lên tren đảo Hoàng $\mathrm{Sa}$ (Pattle) vào năm 1938 với dòng chữ "Cộng hòa Pháp-Vương quốc An Nam-Vùng đảo Hoàng Sa-1816-đảo Pattle 1938". Trên vùng đảo Hoàng $\mathrm{Sa}$, một trạm hải đăng và một trạm vô tuyến điện đã được đặt trên đảo Hoàng Sa. Các công việc đó cũng được tiến hành trên trên vùng đảo Trường $\mathrm{Sa}$, trên đảo $\mathrm{Ba}$ Bình (Itu Aba) [6].

Ngày 30/3/1939 Nhật Bản tuyên bố vùng đảo Trường Sa sẽ đặt dưới quyền kiểm soát của mình. Ngày 4/4/1939, Đại sứ Pháp tại Tokyo liền gửi công hàm phản kháng và tuyên bố phủ nhận quyết định đơn phương của Nhật [2].

Mãi đến ngày 9/3/1945, khi Nhật đảo chính Pháp ở Đông Dương, Nhật mới bắt lính Pháp đồn trú ở vùng đảo Hoàng $\mathrm{Sa}$ làm tù binh. Sau Chiến tranh Thế giới thứ 2, Nhật rút khỏi hai vùng đảo Hoàng $\mathrm{Sa}$ và Trường $\mathrm{Sa}$ và một phân đội lính Pháp đã đổ bộ từ tàu Savorgnan de Brazza lên thay thế quân Nhật từ tháng $5 / 1945$, nhưng đơn vị này chỉ ở đây vài tháng. Trong thời gian từ ngày 20 đến ngày 27/5/1945, Đô đốc D’Argenlieu, Cao ủy Pháp ở Đông Dương cũng đã phái tốc hạm L'Escamouche ra nắm tình hình đảo Hoàng $\mathrm{Sa}$ (Pattle) thuộc vùng đảo Hoàng Sa [2].

Với một số minh chứng nêu trên, có thể khẳng định rằng: suốt trong thời gian đại diện cho Việt Nam về mặt đối ngoại, chính phủ Pháp chưa bao giờ tuyên bố phủ nhận chủ quyền của Vương quốc An Nam (tức nước Cộng hòa xã hội chủ nghĩa Việt Nam ngày nay) ở hai vùng đảo Hoàng $S a$ và Trường $S a$ và luôn luôn khẳng định chủ quyền của Việt Nam đối với các vùng đảo Hoàng $\mathrm{Sa}$ và Trường $\mathrm{Sa}$, đồng thời liên tục phản kháng những hành động xâm phạm nghiêm trọng chủ quyền của Việt Nam ở hai vùng đảo đó. Mặc dù trong giai đoạn này bắt đầu có một số nước lên tiếng đòi hỏi chủ quyền vô lý ở một số đảo nhưng tất cả đều bị chính quyền Pháp kiên quyết phản đối. Những tư liệu lịch sử nói trên cho thấy, người Pháp cũng như người Việt trong thời điểm này chưa bao giờ từ bỏ chủ quyền của Việt Nam trên hai vùng đảo Hoàng $\mathrm{Sa}$ và Trường $\mathrm{Sa}$. Cho đến khi thua trận rút khỏi Đông Dương, Chính phủ Pháp cũng đã bàn giao quyền quản lý vùng biển này lại cho một chính phủ tuy do Pháp dựng lên nhưng cũng là của người Việt Nam. Hay nói cách khác, trong xuyên suốt lịch sử, kể cả đến thời điểm sau Chiến tranh Thế giới thứ II, Trung Quốc không hề sở hữu cái gọi là chủ quyền tại hai vùng đảo Hoàng $\mathrm{Sa}$ và Trường $\mathrm{Sa}$.

Triều đình Việt Nam trong thời kỳ này đã ủy quyền cho Pháp trong quan hệ đối ngoại, song vẫn chưa bao giờ từ bỏ chủ quyền của Việt Nam tại hai vùng đảo Hoàng Sa và Trường Sa. Cụ thể, vào ngày 29 tháng 2 năm Bảo Đại thứ 13 (nhằm ngày 30/3/1938), Hoàng đế Bảo Đại ký Dụ số 10 có nội dung: "Chiếu theo các cù lao Hoàng $\mathrm{Sa}$ thuộc về chủ quyền nước Nam đã từ lâu và dưới các tiên triều, các cù lao ấy thuộc về địa hạt tỉnh Nam Ngãi. Đến đời Đức Thế Tổ Cao Hoàng Đế vẫn để y như cũ là vì nguyên trước sự giao thông với các cù lao ấy đều do các cửa bể tỉnh Nam Ngãi. Nhờ sự tiến bộ trong việc hàng hải nên việc giao thông ngày nay có thay đổi, vả lại viên đại diện Chính phủ Nam Triều cũng phải ra kinh lý các cù lao ấy cùng qua các đại diện Chính phủ bảo hộ có tâu rằng nên tháp các cù lao Hoàng $\mathrm{Sa}$ vào địa hạt tỉnh Thừa Thiên thời được thuận lợi hơn... Trước chuẩn tháp nhập các cù lao Hoàng $\mathrm{Sa}$ vào địa hạt tỉnh Thừa Thiên; về phương diện hành chính, các cù lao ấy thuộc dưới quyền quán hiến tỉnh ấy" [3].

Ngoài ra, còn có châu bản ngày 15 tháng 2 năm 1939 của triều Bảo Đại khen thưởng những người có công trong việc bảo vệ Trường $\mathrm{Sa}$ - Hoàng $\mathrm{Sa}$ do gia đình nhà nghiên cứu văn hóa Phan Thuận An hiến tặng. Châu bản này thậm chí còn có dấu tích bút phê "chuẩn y" bằng mực đỏ của vua Bảo Đại cùng chữ ký tên viết tắt là $\mathrm{BD}$ (tức Bảo Đại). Các chuyên gia lịch sử và pháp lý trong nước và quốc tế đều nhận định rằng, các châu bản triều Nguyễn chính là những giá trị lịch sử khẳng định chủ quyền lãnh thổ của Việt Nam, bởi với những ngày tháng cụ thể, nhân vật cụ thể cho chúng ta thấy rằng, trước khi chiến tranh thế giới thứ hai xảy ra thì chủ quyền của Việt Nam vẫn được khẳng định một cách rõ ràng trên vùng biển 
Đông nói chung và Trường Sa, Hoàng Sa nói riêng [3].

\section{Việc bảo vệ và thực hiện chủ quyền của Việt Nam đối với các vùng đảo Hoàng Sa và Trường Sa từ chiến tranh thế giới thứ hai đến năm 1975}

Thời kỳ Chiến tranh thế giới thứ hai, Đế quốc Nhật Bản chiếm một số đảo ở Biển Đông và sử dụng đảo $B a$ Bình làm căn cứ tàu ngầm cho các chiến dịch ở Đông Nam Á. Ngày 9/3/1945, Đơn vị Đông Dương của Pháp trên vùng đảo Hoàng Sa bị hải quân Nhật bắt làm tù binh. Người Nhật chỉ rút khỏi vùng đảo Hoàng Sa vào năm 1946. Ngay sau đó, một phân đội bộ binh Pháp đổ bộ từ tầu Savorgnan de Brazza đến thay thế ngay từ tháng 5 năm 1946, nhưng chỉ ở đó được vài tháng. Các toán quân Tưởng Giới Thạch lấy cớ giải giáp quân đội Nhật Bản đã đổ bộ lên Hoàng Sa vào tháng 11/1946 và lên một đảo của vùng đảo Trường Sa vào tháng 12/ 1946 [4]. Ngày 2/5/1945, Tuyên ngôn Postdam được ký kêt. Ngày 15/8/ 1945, Nhật Bản đầu hàng quân Đồng Minh. Nước Pháp chủ trương giành lại quyền kiểm soát ở Đông Dương [4]. Ngày 28/2/1946 Hiệp ước Pháp Trung được ký kết ở Trùng khánh, theo đó Pháp thay thế quân đội Tưởng Giới Thạch ở Bắc Kỳ. Nhưng ngày 6/3/1946, nước Pháp ký với Chính phủ VNDCCH Hiệp định, theo đó, nước Pháp công nhận Việt Nam dân chủ cộng hòa là thành viên của Liên hiệp Pháp. Đồng thời, Pháp đã thúc đẩy việc lập ra một chính phủ Việt Nam thứ hai (Quốc gia Việt Nam) được hợp thức hóa bởi Hiệp định ký ngày 8/3/1949 và các Hiệp định Giownevo năm 1954 đã tạo ra sự tồn tại của hai chính phủ Việt Nam với việc chấm dứt cuộc chiến tranh Đông Dương [4].

Ngày 7 hoặc 13/1/1947, lợi dụng tình trạng các đảo không có sự chiếm đóng của nhà chức trách Pháp, Trung Quốc cho quân đổ bộ lên đảo Phú Lâm (Woody) thuộc vùng đảo Hoàng Sa. Chính phủ Pháp đã chính thức phản đối sự chiếm đóng bất hợp pháp đó, đồng thời yêu cầu Trung Hoa Dân Quốc rút quân khỏi các đảo đã chiếm đóng trên biển Đông [10]. Ngay sau đó, Pháp đã gửi một đơn vị lính Pháp và Việt Nam đến đặt đồn lính ở đảo Hoàng Sa. Từ ngày $25 / 2$ đến 4/7/1947, tại Paris, một cuộc thương lượng được tiến hành giữa Chính phủ Pháp và Trung Quốc. Tại đây, Chính phủ Trung Quốc đã từ chối không chấp nhận việc nhờ trọng tài quốc tế giải quyết do Pháp đề xuất [4]. Như vậy, thêm một lần nữa Trung Quốc từ chối giải quyết tranh chấp thông qua thiết chế thứ $\mathrm{ba}$, càng chứng tỏ sự thất lý và phi pháp của họ ở Hoàng $\mathrm{Sa}$ và Trường $\mathrm{Sa}[2]$

Như vậy, sau Chiến tranh Thế giới lần thứ II, yêu sách chủ quyền của Trung Quốc (Trung Hoa Dân Quốc) bắt đầu lộ rõ.

Để củng cố luận cứ khẳng định yêu sách tham vọng chủ quyền đối với hai vùng đảo Hoàng Sa và Trường Sa của Việt Nam, phía Trung Quốc thường lấy Hiệp ước San Francisco năm 1951 và Hiệp ước hoà bình Trung - Nhật năm 1952 như là một trong những "chứng cứ pháp lý" quan trọng để khẳng định rằng: Sau Chiến tranh thế giới lần thứ hai, Nhật Bản đã từ bỏ tất cả quyền, danh nghĩa và yêu sách đối với hai vùng đảo Hoàng $\mathrm{Sa}$ và Trường $\mathrm{Sa}$ (mà Trung Quốc gọi là Tây $\mathrm{Sa}$ và $\mathrm{Nam} \mathrm{Sa}$ ) và đã chuyển giao các vùng đảo trên cho đại diện Trung Quốc (?!). Phía Trung Quốc còn cho rằng Điều 2 , Hiệp ước hoà bình Trung - Nhật năm 1952 đã ghi lại lời văn của điều 2 Hiệp ước hoà bình San Francisco [11] ngày 8/9/1951 (có hiệu lực từ ngày 29/4/1952) công nhận chủ quyền của Trung Quốc đối với các vùng đảo này (?!)

Lập luận và yêu sách của Trung Quốc đã đặt ra một loạt các vấn đề cần phải được làm rõ trên cơ sở của thực tế lịch sử và trên nền tảng các quy định của luật quốc tế hiện đại, cụ thể [2] :

- Thứ nhất, Sau Chiến tranh thế giới lần thứ hai, Nhật Bản có tuyên bố từ bỏ mọi quyền, danh nghĩa và đòi hỏi đối với hai vùng đảo Hoàng Sa và Trường Sa hay không?

- Thứ hai, Hiệp ước San Francisco năm 1951 và Hiệp ước hoà bình Trung - Nhật năm 1952 có công nhận chủ quyền của Trung Quốc đối với các vùng đảo này hay không? 
- Thứ ba, Trên thực tế Nhật Bản có bàn giao các vùng đảo này cho đại diện Trung Quốc như người Trung Quốc khẳng định hay không?

Tuy nhiên, nội dung và tinh thần của Hiệp ước San Francisco năm 1951, Hiệp ước hoà bình Trung - Nhật năm 1952 và những văn kiện quốc tế như Tuyên bố Cai Rô năm 1943, Tuyên bố Potsdam năm 1945, là những văn kiện pháp lý quốc tế có liên quan đến vấn đề lãnh thổ của Trung Quốc và hai vùng đảo Hoàng $\mathrm{Sa}$ và Trường $\mathrm{Sa}$, và sự kiện giải giáp quân đội Nhật Bản tại hai vùng đảo Hoàng $\mathrm{Sa}$ và Trường $\mathrm{Sa}$ lại hoàn toàn khác với tất cả những gì mà Trung Quốc viện dẫn. Cụ thể là:

Khi Chiến tranh thế giới lần thứ II còn đang tiếp diễn, ngày 27/11/1943 tại Hội nghị Cairo (Ai Cập), ba cường quốc đồng minh đại diện bởi Tồng thống Hoa Kỳ Roosevelt, Thủ tướng Anh Churchill và Tổng thống Trung Hoa Dân Quốc Tưởng Giới Thạch đã ký Tuyên bố Cairo, theo đó: "Phải tước bỏ quyền của Nhật Bản trên tất cả các hải đảo ở Thái Bình Dương mà Nhật Bản đã cuõong đoạt hay chiếm đóng tù đầu Chiến tranh thế giới lần thư nhất và trả lại Trung Hoa Dân quốc tất cả các lãnh thổ đã bi Nhật Bản cuoóp của Trung Hoa, nhu Mãn Châu, Đài Loan và Bành Hồ, và trục xuất Nhật Bản khỏi tất cả các lãnh thổ khác mà Nhật chiếm được bằng vũ lưc" [12]. Các vùng đảo Hoàng Sa và Trường Sa không hề được đề cập đến trong điều ước quốc tế quan trọng này (với sự tham gia của đại diện Trung Quốc). Như vậy, Tuyên bố khẳng định Nhật Bản chỉ chiếm của Trung Quốc các vùng lãnh thổ như: Mãn Châu, Đài Loan và Bành Hồ và buộc Nhật Bản phải trả cho Trung Quốc những vùng lãnh thổ này. Tuyên bố không coi hai vùng đảo Hoàng Sa và Trường Sa là lãnh thổ của Trung Quốc bị Nhật Bản xâm chiếm, vì vậy, không nói gì đến việc trao trả lại cho Trung Quốc. Nếu hai vùng đảo Hoàng $\mathrm{Sa}$ và Trường $\mathrm{Sa}$ đúng là lãnh thổ của Trung Quốc và bị Pháp, Nhật Bản xâm chiếm thì không có lý gì tại Hội nghị này Trung Hoa Dân quốc không đòi lại chủ quyền đối với hai vùng đảo này khi họ là một trong các nước đồng minh trực tiếp tham gia soạn thảo ra văn kiện trên. Sự im lặng của Trung Hoa Dân quốc, là một bên tham gia bản Tuyên cáo và đích thân
Tổng thống Tưởng Giới Thạch đã có mặt tại các cuộc hội đàm kéo dài nhiều ngày ở Hội nghị Cairo nhưng không hề có sự đề cập đến việc chuyển giao hai vùng đảo Hoàng $\mathrm{Sa}$ và Trường Sa cho Trung Quốc là chỉ có thể lý giải rằng, chính đại diện Trung Quốc lúc bấy giờ cũng thừa biết là các vùng đảo Hoàng $\mathrm{Sa}$ và Trường $\mathrm{Sa}$ không phải là lãnh thổ của Trung Quốc. Thêm một lần nữa càng chứng tỏ rằng: không chỉ các cường quốc tham gia kết ước và cộng đồng quốc tế đương đại mà còn chính bản thân đại diện của Trung Quốc đều nhận thức rõ rằng: Hoàng $\mathrm{Sa}$ và Trường $\mathrm{Sa}$ chưa bao giờ là lãnh thổ của Trung Quốc.

Năm 1931, Nhật Bản xâm chiếm Mãn Châu với ý đồ thành lập Nhà nước Mãn Châu. Trước đó, trong Chiến tranh Trung-Nhật (1894-1895), đảo Đài Loan và vùng đảo Bành Hồ cũng bị Nhật Bản chiếm cứ bằng vũ lực. Vì vậy, trong Tuyên Cáo Cairo năm 1943, Tổng thống Roosevelt và Thủ tướng Churchill tán thành đề nghị của Tổng thống Tưởng Giới Thạch về việc Đồng Minh sẽ bàn giao Mãn Châu, Đài Loan và vùng đảo Bành Hồ cho Trung Quốc khi chiến tranh kết thúc.

Tại Biển Đông, hai vùng đảo Hoàng Sa và Trường Sa của Việt Nam cũng đã bị Nhật Bản chiếm cứ bằng vũ lực khi bắt đầu Chiến tranh Thế giới thứ II. Năm 1938, Nhật Bản chiếm 03 (ba) đảo tại Hoàng Sa là Phú Lâm, Lincoln và Hữu Nhật (Robert). Năm 1939, Nhật Bản ngang ngược công bố chủ quyền tại hai vùng đảo Hoàng Sa Trường Sa và đổi tên Hoàng $\mathrm{Sa}$ thành Hirata Gunto, Trường Sa thành Shinnan Gunto.

Theo pháp luật quốc tế hiện đại, Tuyên bố Cairo năm 1943 là một điều ước quốc tế không những xác lập quyền mà còn ấn định những nghĩa vụ quốc tế có giá trị ràng buộc các quốc gia hữu quan. Vì vậy, với tư cách là một bên tham gia điều ước quốc tế, đặc biệt là điều ước quốc tế về lãnh thồ- biên giới , với tính hiệu lực tuyệt đối (lentis possibilitas iuris), Trung Quốc - dù là Trung Hoa Dân Quốc hay Cộng Hòa Nhân dân Trung Hoa (quốc gia kế thừa chủ quyền) - đều có nghĩa vụ tuân thủ cam kết quốc tế này. Ngay thời gian sau đó, cả hai phía Trung Hoa Dân Quốc và Cộng Hòa Nhân dân Trung Hoa đều thừa nhận giá trị pháp lý của bản 
Tuyên cáo này. Ví dụ, ngày $04 / 12 / 1950$, Chu Ân Lai - lúc này là Bộ trưởng Bộ Ngoại giao Cộng hòa Nhân dân Trung Hoa - đã tuyên bố tán thành Bản Tuyên bố Cairo năm 1943 là "văn kiện lịch sử quốc tế mà Hoa Kỳ, Anh Quốc và Trung Quốc đã ký kết để làm cơ sở Hiệp ước San Francisco ngày 8/9/1951". Ngày 8/02/1955, mười hai năm sau khi ký Tuyên bố Cairo, Tổng thống Trung Hoa Dân Quốc Tưởng Giới Thạch cũng đã thừa nhận giá trị của Tuyên bố Cairo và Tuyên ngôn Potsdam là: "Tôi còn nhớ năm 1943, cố Tổng thống Hoa Kỳ Roosevelt và Thủ tướng Anh Churchill đã cùng tôi họp Hội nghị Cairo để thảo luận về những vấn đề liên quan đến việc tiến hành cuộc chiến tranh chống Nhật. Trong bản Tuyên bố công bố vào ngày bế mạc Hội nghị (27/11/1943), chúng tôi loan báo rằng tất cả các lãnh thổ mà Nhật Bản đã chiếm của Trung Quốc, kể cả Đông Bắc Tỉnh (Mãn Châu), Đài Loan và Bành Hồ, phải được giao hoàn cho Trung Quốc. Bản Tuyên bố này đã được Bản Hiệp ước Potsdam ngày 26/7/1945 thừa nhận và được Nhật Bản chấp nhận thi hành khi đầu hàng.Như vậy, giá trị Tuyên bố Cairo đã được xác lập trên cơ sở những thỏa thuận không ai có thể phủ nhận được" [13].

Tuyên bố Cairo ngày 27/11/1943 cũng đã được đại diện Liên Xô tán thành tại Hội nghị Teheran ngày 30/11/1943 giữa Tổng thống Roosevelt, Thủ tướng Churchill và Nguyên soái Stalin. Trong phiên Hội nghị này, Stalin cho biết ông đã đọc Tuyên cáo Cairo với đầy đủ nội dung của nó và cho rằng việc giao hoàn Mãn Châu, Đài Loan và Bành Hồ cho Trung Quốc là hợp lý. Tuy nhiên, Stalin cũng không hề đề cập đển việc đến chuyển giao vùng đảo Hoàng $\mathrm{Sa}$ và Trường Sa cho Trung Quốc [14]. Theo luật gia người Pháp GS.Monique ChemillierGedreau: "Việc không nói tới các vùng đảo Hoàng Sa và Truờng Sa trong Tuyên cáo Cairo năm 1943 thật là đặc biệt. Nó không thể là kết quả của mọt sư tình cò̀:Không có một bảo luu cũng nhu một tuyên bố riêng rẽ nào của Trung Quốc về vấn đề các lãnh thổ này" [15].

Sau khi Đức Quốc xã đầu hàng Đồng Minh, tháng 7 năm 1945, các nước Mỹ, Anh và Liên Xô tổ chức Hội nghị Potsdam (tại Đức) để thảo luận về tương lai chính trị của các nước Đông Âu và Trung Âu sau Thế chiến thứ II với bản Tuyên bố Potsdam ngày 26-7-1945. Bản Tuyên bố này ấn định thể thức giải giáp quân đội Nhật Bản tại Thái Bình Dương. Để giải giáp quân đội Nhật, Đồng Minh quyết định chia Việt Nam thành hai khu vực, lấy vĩ tuyến 16 làm mốc: quân đội Trung Hoa Dân Quốc có nghĩa vụ giải giáp và hồi hương quân đội Nhật từ vĩ tuyến 16 Bắc, còn quân đội Anh được ủy nhiệm giải giáp quân đội Nhật từ vĩ tuyến 16 vào Nam. Theo Tuyên bố Potsdam, Trung Quốc có nghĩa vụ giải giáp quân đội Nhật từ vĩ tuyến 16 ra Bắc bao gồm cả vùng đảo Hoàng $\mathrm{Sa}$ (tọa lạc từ vĩ tuyến 16, như nhóm Lưỡi Liềm (Crescent Group) phía tây nam tại vĩ độ $16^{\circ} 30$ và Nhóm An Vĩnh (Amphitrite Group) phía đông bắc tại vĩ độ $16^{\circ} 50$ ); còn quân đội Anh có nghĩa vụ giải giáp quân đội Nhật từ vĩ tuyến 16 vào Nam, bao gồm cả tại vùng đảo Trường $\mathrm{Sa}$. Cần lưu ý rằng, việc giải giáp quân sự theo pháp luật quốc tế không thể là sự tiếp thu hay chiếm hữu lãnh thổ. Vì vậy, hiển nhiên cả Anh và Trung Quốc đều không thể có chủ quyền lãnh thổ tại Trường Sa và Hoàng Sa thông qua hành vi giải giáp quân sự được các nước Đồng Minh ủy quyền. Như vậy, vùng đảo Hoàng Sa nằm trong khu vực quân đội Trung Quốc giải giáp quân đội Nhật Bản. Tuy nhiên, cần lưu ý rằng các nước Đồng Minh chỉ đơn thuần giao trách nhiệm giải giáp quân đội Nhật Bản, không chuyển giao chủ quyền, và về pháp lý cũng không có thẩm quyền, trao chủ quyền cho nước có thực hiện trách nhiệm giải giáp. Nhưng theo Thỏa ước Trung - Nhật ngày 28 tháng 2 năm 1946, Trung Quốc đã chuyển giao nhiệm vụ giải giáp quân đội Nhật Bản cho Pháp. Như vậy từ thời điểm đó về mặt pháp lý và trên thực tế, Pháp đã thay thế quân đội Trung Quốc tiếp quản khu vực lãnh thổ Đông Dương ở phía Bắc vĩ tuyến $16 \mathrm{oN}$, trong đó có vùng đảo Hoàng $\mathrm{Sa}$. Thực hiện trách nhiệm được giao, vào tháng 6 năm 1946, Pháp đã cho quân đổ bộ lên đảo Hoàng Sa thuộc vùng đảo Hoàng Sa để tiếp quản vùng đảo này. Đó là hành động hợp pháp, phù hợp với thoả thuận của các nước Đồng Minh và Thoả ước Trung - Nhât ký ngày 28 tháng 2 năm 1946. Lợi dụng chiến tranh toàn 
diện sắp bùng nổ ở Việt Nam, ngày 26 tháng 10 năm 1946, Trung Hoa Dân quốc cho quân đội đổ bộ lên đảo Phú Lâm thuộc vùng đảo Hoàng Sa và đảo Itu $A b a$ thuộc vùng đảo Trường $\mathrm{Sa}$. Chính phủ Pháp đã phản đối chính thức sự chiếm đóng bất hợp pháp của Trung Quốc. Ngày 17 tháng 10 năm 1947 thông báo hạm Tonkinois của Pháp được phái đến Hoàng Sa để yêu cầu quân Trung Quốc rút khỏi Phú Lâm. Pháp gửi một phân đội lính trong đó có cả quân lính "Quốc gia Việt Nam" đến đóng một đồn ở đảo Pattle (Hoàng $\mathrm{Sa}$ ). Chính phủ Trung Quốc phản kháng và các cuộc thương lượng được tiến hành từ ngày 25 tháng 2 đến ngày 4 tháng 7 năm 1947 tại Paris. Pháp đề nghị nhờ trọng tài quốc tế giải quyết tranh chấp nhưng chính quyền Tưởng Giới Thạch từ chối. Tháng 4 năm 1949, Đổng Lý Văn Phòng của quốc trưởng Bảo Đại là hoàng thân Bửu Lộc, trong một cuộc họp báo tại Sài Gòn đã công khai khẳng định lại chủ quyền của Việt Nam đã từ lâu đời trên vùng đảo Hoàng $\mathrm{Sa}$ và Trường $\mathrm{Sa}$. Vào tháng 4 năm 1950, quân lính Trung Hoa Dân Quốc rút hết quân khỏi vùng đảo Hoàng $\mathrm{Sa}$ và Trường $\mathrm{Sa}$. Đồn lính của Pháp đóng ở đảo Hoàng $\mathrm{Sa}$ (Pattle) vẫn được duy trì. Trước khi rút khỏi Việt Nam, Chính phủ Pháp chính thức chuyển giao cho chính quyền miền Nam Việt Nam quyền quản lý các vùng đảo Hoàng $S a$ và Trường Sa. Hành động xâm chiếm một số đảo tại hai vùng đảo Hoàng $S a$ và Trường $S a$ của Trung Hoa Dân quốc là bất hợp pháp vì hai lý do. Thứ nhất, Trung Hoa Dân quốc đã bàn giao nhiệm vụ tiếp quản vùng đảo Paracel (Hoàng Sa) cho người Pháp. Thứ hai, trách nhiệm giải giáp quân Nhật tại vùng đảo Trường Sa đã được giao cho quân đội Anh - Ân.

Và, về việc giải quyết những vùng lãnh thổ mà Nhật Bản đã chiếm của các nước, Tuyên bố Potsdam chỉ quy định đơn giản là: "Các điều khoản của Tuyên bố Cairo sẽ được thi hành". "Các điều khoản của Tuyên bố Cairo sẽ được thi hành" có nghĩa là Nhật Bản phải trả lại cho Trung Quốc các vùng lãnh thổ như: Mãn Châu, Đài Loan và Bành Hồ, là những vùng lãnh thổ của Trung Quốc đã bị Nhật Bản chiếm đoạt trước kia. Như vậy, không có một nội dung nào trong Tuyên bố Potsdam coi hai vùng đảo
Hoàng $\mathrm{Sa}$, Trường $\mathrm{Sa}$ là của Trung Quốc bị Nhật Bản chiếm và phải trả lại cho Trung Quốc. Sự kiện này càng chứng tỏ rằng, khác với Mãn Châu, Đài Loan và Bành Hồ, các nước Đồng Minh không thừa nhận Hoàng $\mathrm{Sa}$, Trường $\mathrm{Sa}$ thuộc chủ quyền của Trung Quốc, và như vậy đã gián tiếp khẳng định chủ quyền không thể tranh cãi của Việt Nam đối với vùng đảo Hoàng $\mathrm{Sa}$ và Trường $\mathrm{Sa}$ [2].

Ngay sau khi chấm dứt Thế chiến thứ II, chính quyền Pháp tại Đông Dương đã khôi phục lại sự có mặt trên hai vùng đảo Hoàng $\mathrm{Sa}$ và Trường $\mathrm{Sa}$ - từng bị quân đội Nhật chiếm đóng trong chiến tranh thế giới. Các tàu chiến Escarmouche và Savorgnan de Blazza trong thời gian từ ngày $20 / 5$ đến ngày $6 / 6 / 1946$ đã ra thám sát lại vùng đảo Hoàng Sa. Các đảo đều bị bỏ hoang. Hải quân Nhật đã rời các đảo này sau khi đã phá hủy tất cả các công trình xây dựng và các cảng tại đó [16]

Một phân đội của Pháp đã đổ bộ lên đảo Hoàng Sa để chiếm lại quần đảo [17]. Họ đã thực hiện việc chiếm đóng lại cho An Nam, đồng thời khẳng định cả hai yếu tố vật chất và tinh thần. Ngày 1/10/1949, nước CHND Trung Hoa ra đời. Chính quyền Pháp vẫn tiếp tục duy trì các trại đồn trú trên đảo Hoàng $\mathrm{Sa}$ để bảo vệ trạm khí tượng "bằng mọi phương tiện" trong trường hợp bị tấn công từ bên ngoài [18]

Từ cuối năm 1947, Chính phủ Pháp thành lập ra chính quyền thân Pháp, được gọi là Quốc gia Việt Nam (Estat du Vietnam) do cựu Hoàng đế Bảo Đại đứng đầu nằm trong Liên hiệp Pháp [19].

Ngày 8/3/1949, Tổng thống Pháp Vincent Auriol và Quôc trưởng Quốc gia Việt Nam Bảo Đại ký Hiệp ước công nhận nền độc lập, thống nhất và toàn vẹn lãnh thổ của Việt Nam. Ngay sau đó, nhiều quốc gia phương Tây, có cả các nước Anh, Mỹ đã chính thức công nhận quốc gia Việt Nam . Ngày 4/6/1949, Tổng thống Pháp Vincent Auriol ký đạo luật 49-733 kêt thúc quá trình trao trả Nam Kỳ cho Việt Nam, chấm dứt quy chế "lãnh thố Hải ngoại của Pháp" đối với toàn bộ vùng đất Nam Kỳ. Vùng đảo Trường $\mathrm{Sa}$ từ năm 1933 đã là một đơn vị hành chính chính thức của tỉnh Bà Rịa thuộc Nam Kỳ, nên vùng đảo Trường $\mathrm{Sa}$ cũng phải 
được trao trả cho Quốc gia Việt Nam theo đạo luật này [19] là lẽ tất nhiên, không thể bàn cãi!

Tháng 4 năm 1949, Hoàng thân Bửu Lộc là đổng lý Văn phòng Chính phủ Quốc gia Việt Nam trong một cuộc họp báo tại Sài Gòn đã tuyên bố khẳng định lại các vùng đảo Hoàng Sa và Trường Sa là thuộc Vương triều An Nam.

Ngày 14/10/1950, Chính phủ Pháp đã chính thức trao lại cho Quốc gia Việt Nam (chính phủ Hoàng đế Bảo Đại) việc quản lý và phòng thủ vùng đảo Hoàng Sa. Tổng quản Trung Bộ, ông Phan Văn Giáo đã ra Hoàng Sa chủ trì lễ chuyển giao quyền hành quản lý này [19]. Tuy nhiên, các nhóm quân Pháp vẫn tiếp tục ở lại vùng đảo Hoàng Sa cho tới năm 1956.

Ngày 8-9-1951, sáu năm sau khi thành lập Liên hợp quốc (tháng 6 năm 1945), 50 quốc gia Đồng minh lại nhóm họp tại San Fransisco để ký Hiệp ước San Fransisco nổi tiếng với Nhật Bản, nhằm chấm dứt tình trạng chiến tranh, phục hồi và tái thiết Nhật Bản, vãn hồi hòa bình thế giới trong tinh thần hòa giải, hợp tác và hữu nghị theo mục đích và tôn chỉ của Hiến chương Liên hợp quốc.

Theo Điều 2 của Hiệp ước, Nhật Bản khước từ chủ quyền tại đảo Đài Loan và vùng đảo Bành Hồ và một số lãnh thổ trong đó có các vùng đảo Trường Sa và Hoàng $\mathrm{Sa}$.

Khi Nhật Bản tuyên bố khước từ chủ quyền lãnh thổ về Hoàng $\mathrm{Sa}$ và Trường $\mathrm{Sa}$ tại Hội nghị San Francisco năm 1951, các quốc gia tham dự Hội nghị đã phủ nhận chủ quyền của Trung Quốc và mặc nhiên nhìn nhận chủ quyền của Việt Nam tại hai vùng đảo này. Ngày 5-91951, trong phiên họp toàn thể, theo đề nghị của đại diện Liên $\mathrm{X}^{4}{ }^{4}$ Ngoại trưởng Andrei

\footnotetext{
${ }^{4}$ Nước Cộng hòa Nhân dân Trung Hoa được tuyên bố thành lập vào tháng 10 năm 1949 . Tuy nhiên chẳng bao lâu sau đó, một cuộc viếng thăm dài hai tháng của Mao Trạch Đông đã đạt được kết quả với Hiệp ước Hữu nghị và Hợp tác Trung-Xô (1950) bao gồm một khoản cho vay lãi suất thấp của Liên Xô giá trị 300 triệu rúp và liên minh quân sự 30 năm chống hành động xâm lược của Nhật Bản. Đây là một trong những thời kỳ "mặn nồng" giữa Trung Quốc và Liên Xô. Vì vậy, việc Ngoại trưởng Liên Xô đề xuất Hội nghị San Francisco "vơ" cả hai quần đảo Hoàng Sa và Trường $\mathrm{Sa}$ để trao cho Trung Quốc rõ ràng là xuất phát từ động cơ chính trị , nhằm lôi kéo, tranh thủ Trung Quốc mà thôi. Hành động này của đại diện Liên Xô không
}

Gromyko), một tu chính án đã được đưa ra yêu cầu Hội nghị trao một loạt lãnh thổ, trong đó có các vùng đảo Trường $\mathrm{Sa}$ và Hoàng $\mathrm{Sa}(\mathrm{Nam} \mathrm{Sa}$ và Tây $\mathrm{Sa}$ ) cho Trung Quốc. Nhưng tu chính án này đã bị Hội nghị bác bỏ với 46 phiếu chống, 03 phiếu thuận (Ba Lan, Tiệp Khắc và Liên Xô) và 01 phiếu trắng [15].

Ngày 07-9-1951, trong phiên họp toàn thể lần thứ 7 của Hội nghị San Fransisco, Thủ tướng kiêm Ngoại trưởng Trần Văn Hữu đại diện cho Chính phủ Quốc gia Việt Nam, Trưởng Phái đoàn Việt Nam đã dõng dạc tuyên bố chủ quyền của Việt Nam tại các vùng đảo Trường $\mathrm{Sa}$ và $\mathrm{Hoàng} \mathrm{Sa}$, khẳng định vùng đảo Hoàng $\mathrm{Sa}$ và vùng đảo Trường $\mathrm{Sa}$ là bộ phận của lãnh thổ Việt Nam: “...để dập tắt nhũng mầm mống các tranh chấp sau này, chúng tôi khăng định chủ quyền đã có tù lâu đời của chúng tôi đối với các vùng đảo Truoòng $S a$ và Hoàng $S a$ ". Tuyên bố đó không gặp sự chống đối hoặc bảo lưu nào của đại diện 51 quốc gia tham dự Hội nghị (kể cả Liên Xô).

Năm 1951, Nhật Bản kí vào Hiệp ước San Francisco và từ bỏ mọi quyền đối với vùng đảo Trường Sa. Hội nghị San Francisco đã bác bỏ đề nghị giao hai vùng đảo Hoàng $\mathrm{Sa}$ và Trường Sa cho Trung Quốc với số phiếu hầu như tuyệt đối 46/50. Cũng tại Hội nghị San Franciso này, Thủ tướng kiêm Ngoại trưởng Trần Văn Hữu của Quốc gia Việt Nam đã tuyên bố rằng hai vùng đảo Hoàng $\mathrm{Sa}$ và Trường $\mathrm{Sa}$ là lãnh thổ Việt Nam. Sau khi người Pháp rời khỏi Việt Nam theo quy định của Hiệp định Genève 1954, quyền kiểm soát các đảo thuộc về quân đội Quốc gia Việt Nam và kế tiếp là quân đội Việt Nam Cộng hòa. Sau sự kiện Tomás Cloma, ngày 1 tháng 6 năm 1956, Ngoại trưởng Việt Nam Cộng hoà Vũ Văn Mẫu tái khẳng định chủ quyền của Việt Nam đối với Trường $\mathrm{Sa}$ và Hoàng Sa [20]. Ngày 02 tháng 6 năm 1956, Pháp cũng nhắc lại cho Philippines biết về quyền của Pháp từ năm 1933 [4]. Ngày 22 tháng 8 năm 1956, tàu HQ-04 Tuỵ Động của Hải quân Việt Nam Cộng hòa viếng thăm một số đảo thuộc Trường $\mathrm{Sa}$, thượng cờ và dựng bia

hề dựa trên bất kỳ căn cứ lịch sử và pháp lý nào, và vì vậy, đã bị cộng đồng quốc tế tẩy chay là điều dễ hiểu. 
ghi chủ quyền. Ngày 22 tháng 10 cùng năm, Tổng thống Việt Nam Cộng Hòa Ngô Đình Diệm ký Sắc lệnh số $143-\mathrm{NV}$ về việc đổi tên các tỉnh thành miền Nam Việt Nam; văn bản ghi "Hoàng Sa (Spratley)" (sic) thuộc tỉnh Phước Tuy [21].

Nhu vậy, bằng việc bác bỏ và phủ quyết (với số phiếu hầu nhu tuyệt đối) của Hội nghị San Francisco năm 1951 về việc đòi trao hai vùng đảo Hoàng $S a$ và Truờng $S a$ cho Trung Quồc và sự tuyên bố khẳng định chủ quyền của Việt Nam đối với Hoàng Sa và Truòng Sa trước 50 quốc gia hội viên sáng lập Liên hợp quốc tại Hội nghị San Francisco chứng tỏ rằng các vùng đảo Hoàng Sa và Truòng Sa đã được các quốc gia trên thế giới thù̀a nhận là thuộc chủ quyền lãnh thổ của Việt Nam. Việc các quốc gia Đồng Minh hội viên Liên hiệp quốc thừa nhận chủ quyền của Việt Nam tại các vùng đảo Hoàng Sa và Trường Sa có giá trị pháp lý quốc tế vững chắc và không thể bị bác bỏ [22].

Một minh chứng nữa là khi ký một điều ước quốc tế với Nhật ngày 28/4/1952, Trung Hoa Dân quốc đã ghi nhận việc từ bỏ mọi quyền của Nhật đối với các đảo, nhưng lại không đưa vào Hiệp ước song phương này bất kỳ điều khoản nào về sự quy thuộc của hai vùng đảo Hoàng $\mathrm{Sa}$ và Trường Sa.

Theo luật gia người Pháp GS.Monique Chemillier- Gendreau, "chính các điều khoản của các hòa uớc với Nhật Bản (tập thể hay riêng rẽ), các tuyên bố nêu trong đó hay làm nguồn gốc cho các hiệp ước đó, cho thấy sau năm 1949, Trung Hoa Dân quốc là nước bảo đảm sư liên tuc của Chính phủ Trung Quốc duy nhất truơóc đó, đã không khẳng định bất kỳ yêu sách nào trên các vùng đảo trong dịp có Bản Tuyên cáo Cairo và đã thù̀a nhận song phưong sụ tù bỏ của Nhật Bản mà không đura ra yêu sách của chính mình" đối với hai vùng đảo Hoàng Sa và Truoòng Sa... cho phép kết luận là Trung Hoa Dân quốc khi đó đã tù bỏ viẹc khằng định các quyền của mình đối với các hòn đảo tranh chấp" [15]. Đồng thời, "Bằng sự im lạng trong bản Tuyên cáo Cairo năm 1943 hay trong Hòa ước song phuơng với Nhật Bản năm 1952, Trung hoa Dân Quốc đã tù bỏ các quyền của mình. Yêu sách của Cộng hòa nhân dân Trung Hoa thể hiện tù̀ năm 1951 không phải nhu một sụ khẳng định một danh nghĩa lặp lại của thời kỳ trước, cũng không phải nhu một quyền được rút ra tù tính thực sư của sư quản lý. Chí có lợi thế của ho, đó là sự chiếm đóng bằng vũ lự năm 1956 và năm 1974" [15] và sau đó là năm 1988 và 1992 .

Ba năm sau Hội Nghị San Francisco 1951, Hội Nghị Geneva 1954 với sự tham dự của 09 quốc gia, gồm 05 cường quốc: Hoa Kỳ, Anh, Pháp, Liên Xô và Trung Quốc đã minh thị xác nhận chủ quyền của Việt Nam tại các vùng đảo Hoàng $\mathrm{Sa}$ và Trường Sa tại Hiệp định Genevơ ký ngày 21-7-1954. Trên thực tế, khi trở lại Việt Nam sau chiến tranh thế giới thứ hai, trong vùng chiếm đóng của mình, nhà cầm quyền Pháp đã phái chiến hạm ra vùng đảo Hoàng $\mathrm{Sa}$, xây dựng lại trạm khí tượng trên đảo Hoàng $\mathrm{Sa}$ và chống lại các hành động lấn chiếm của Trung Quốc. Năm 1953, tàu Ingenieur en elef Girod của Pháp khảo sát ở vùng đảo Hoàng $\mathrm{Sa}$ về hải dương, địa chất, địa lý, môi sinh.

Chính phủ Việt Nam Cộng hòa, sau đó là cả chính phủ Cách mạng lâm thời Cộng hòa miền Nam Việt Nam, cũng đều thưc hiện chủ quyền của Việt Nam đối với vùng đảo Hoàng $S a$ và vùng đảo Truờng $S a$. Dưới đây là một số minh chứng cụ thể [2]:

Theo các Hiệp định tại Geneva năm 1954, các vùng đảo Hoàng $\mathrm{Sa}$ và Trường $\mathrm{Sa}$ đã được chuyển giao cho chính quyền miền Nam Việt Nam kiểm soát. Vì vậy, tháng 4 năm 1956, khi Pháp rút quân khỏi Đông Dương kể cả ở Hoàng $\mathrm{Sa}$ và Trường $\mathrm{Sa}$, Chính quyền Việt Nam Cộng hòa tiếp quản các vùng đảo Trường $S a$ và nhóm đảo phía Tây vùng đảo Hoàng Sa (nhóm đảo Lưỡi Liềm-Nguyệt Thiềm). Còn nhóm đảo phía Đông Hoàng Sa (nhóm An Vĩnh ), do phía Việt Nam chưa kịp ra tiếp quản, đã bị quân đội Trung Quốc chiếm đóng.

Ngày 8 tháng 6 năm 1956, Bộ trưởng Ngoại giao của chính quyền Nam Việt Nam ra tuyển bố chủ quyền của Việt Nam đối với vùng đảo Hoàng Sa và Trường Sa.

Năm 1956, Sở Hầm mỏ, kỹ nghệ và tiểu công nghiệp miền Nam tổ chức một cuộc khảo sát với sự giúp đỡ của hải quân Chính quyền Nam Việt Nam trên 04 đảo: Hoàng Sa (pattle), 
Quang Ảnh (Money), Hữu Nhật (Robert), Duy Mộng (Drumond).

Liên tiếp trong các năm 1956-1959, Chính quyền Việt Nam Cộng hòa đã ban hành một loạt các đạo luật nhằm quản lý hữu hiệu vùng đảo Trường $\mathrm{Sa}$, như : Sắc lệnh số $143 / \mathrm{NV}$ ngày 22/10/1956, Nghi định số 76/BNV/HC/ND ngày $20 / 3 / 1958$ và Sắc lệnh số $34 / \mathrm{NV}$ ngày 29/1/1959 sáp nhập vùng đảo Trường Sa trực thuộc tỉnh Phước Tuy.

Trong thời kỳ 1961-1963, Việt Nam Cộng hoà tiếp tục cho người ra quản lý và dựng bia trên nhiều đảo vùng đảo Hoàng Sa và Trường Sa. Ngày 13 tháng 7 năm 1961, Tổng thống Ngô Đình Diệm ban hành Sắc lệnh số 175-NV [23] thành lập một đơn vị hành chính cho toàn bộ vùng đảo Hoàng $\mathrm{Sa}$, đặt tên là xã Định Hải, quận Hòa Vang, tỉnh Quảng Nam. Từ 1961 đến 1963, chính quyền Sài Gòn lần lượt cho xây bia chủ quyền ở các đảo chính của vùng đảo Trường Sa: Trường $\mathrm{Sa}$, An Bang, Song Tử Tây, Song Tử Đông, Thị Tứ, Loại Ta.

Năm 1961, tàu HQ-02 Vạn Kiếp và HQ-06 Vân Đồn thăm Song Tử Tây - Thị Tứ - Loại Ta - An Bang; năm 1962, tàu Tuỵ Động và HQ-05 Tây Kết thăm Trường Sa - Nam Yết; năm 1963, ba tàu gồm HQ-404 Hương Giang, HQ-01 Chi Lăng và HQ-09 Kì Hoà đã dựng bia trên Trường Sa (19 tháng 5), An Bang ( ngày 20 tháng 5), Thị Tứ - Loại Ta (22 tháng 5 ) và Song Tử Đông - Song Tử Tây (24 tháng 5) [7]. Tuy nhiên, Hải quân Việt Nam Cộng hòa không duy trì sự hiện diện liên tục ở vùng đảo Trường $\mathrm{Sa}$ do điều kiện khí hậu khắc nghiệt và vướng vào cuộc chiến tranh Việt Nam [20] do Mỹ cầm đầu. Ngày 21 tháng 10 năm 1969: Thủ tướng Chính phủ Việt Nam Cộng hòa ký nghị định số 709-BNV/HCĐP để "Sáp nhập xã Định Hải thuộc quận Hòa Vang tỉnh Quảng Nam vào xã Hòa Long cùng quận". Ngày 13 tháng 7 năm 1971, tại Manila Philippines, Bộ trưởng Bộ Ngoại giao Việt Nam Cộng hoà Trần Văn Lắm đã khẳng định chủ quyền của Việt Nam đối với hai vùng đảo Hoàng Sa và Trường Sa. Ngày 6 tháng 9 năm 1973, Bộ Nội vụ Việt Nam Cộng hòa ban hành nghị định số 420-BNV/HCĐP/26 sáp nhập một số đảo chính và các đảo phụ cận vào xã Phước Hải, quận Đất Đỏ, tỉnh Phước
Tuy [24]. Ngày 19 tháng 1 năm 1974, quân đội Trung Quốc tấn công quân đồn trú Việt Nam Cộng hòa và chiếm các đảo phía tây thuộc vùng đảo Hoàng $\mathrm{Sa}$, chiếm đóng phi pháp toàn bộ vùng đảo Hoàng Sa của Việt Nam. Ngay lập tức Bộ Ngoại giao Việt Nam Cộng hòa đã ra văn bản tố cáo hành động xâm lược của Trung Quốc [25]

Ngày 21/10/1969, Thủ tướng Chính phủ Việt Nam Cộng hòa, bằng Sắc lệnh số 709/BNV/HC, đã sát nhập xã Định Hải vào xã Hòa Long cũng thuộc quận Hòa Vang, tỉnh Quảng Nam.

Tháng 7/1973, Viện Khảo cứu nông nghiệp thuộc Bộ phát triển nông nghiệp và điền địa Sài Gòn tiến hành khảo sát Nam $\mathrm{Ai}$ (Nam Yit) thuộc vùng đảo Trường $\mathrm{Sa}$.

Tháng 8/1973, với sự hợp tác của Công ty Nhật Maruben Corporation, Bộ Kế hoạch và phát triển quốc gia Sài Gòn tiến hành khảo sát phốt phát ở vùng đảo Hoàng Sa.

Ngày 6/9/1973, Chính quyền Việt Nam Cộng hòa sáp nhập các đảo Trường $\mathrm{Sa}, \mathrm{An}$ Bang, Itu Aba, Song Tử Đông, Song Tử Tây, Loại Ta, Thị Tứ, Nam Ai, Sinh Tồn và các đảo phụ cận vào xã Phước Hải, quận Đất Đỏ, tỉnh Phước Tuy.

*Có ý thức về chủ quyền tù lâu đời của Việt Nam đối với vùng đảo Hoàng $S a$ và vùng đảo Trường Sa, các chính quyền miền Nam Việt Nam đều bảo vệ chủ quyền đó mỗi khi có nước ngoài biểu thi ý đồ tranh giành hay xâm chiếm đảo nào đó trong hai quần đảo.

Ngày 16/6/1956, khi Cộng hòa nhân dân Trung Hoa, Đài Loan và cộng hòa Philippines đều nhận vùng đảo Trường Sa là của họ, Bộ trưởng Ngoại giao chính quyền Sài Gòn tuyên bố một lần nữa khẳng định chủ quyền của Việt Nam đối với vùng đảo đó.

Ngày 22/02/1959, Chính quyền Sài Gòn bắt giữ một thời gian 82 người dân Cộng hòa nhân dân Trung Hoa đổ bộ lên các đảo Hữu Nhật, Duy Mộng và Quang Hòa trong vùng đảo Hoàng Sa.

Ngày 20/4/1971, Chính quyền Sài Gòn khẳng định một lần nữa vùng đảo Trường $\mathrm{Sa}$ thuộc lãnh thổ Việt Nam, đáp lại đòi hỏi về chủ 
quyền của Malaysia đối với một số đảo trong vùng đảo đó.

Nhân lời tuyên bố của Tổng thống Philippines về vùng đảo Trường Sa, trong cuộc họp báo ngày 10/7/1971, Ngoại trưởng chính quyền Sài Gòn ngày 13/7/1971 khẳng định một lần nữa chủ quyền của Việt Nam đối với vùng đảo đó.

Tháng 1 năm 1974, khi Cộng hòa nhân dân Trung Hoa dùng lực lượng quân sự xâm chiếm nhóm đảo phía Tây nam của vùng đảo Hoàng Sa, ngày 19/1/1974 chính quyền Việt Nam Cộng hòa đã ra tuyên bố lên án Cộng hòa nhân dân Trung Hoa xâm phạm toàn vẹn lãnh thổ của Việt Nam. Ngày 20 tháng 01 năm 1974: Chính phủ Cách mạng Lâm thời Cộng hòa Miền Nam Việt Nam (Mặt trận Dân tộc Giải phóng miền Nam) đã ra Tuyên bố phản đối hành động này của phía Trung Quốc [20]. Đồng thời, ngày 26/1/1974, Chính phủ cách mạng lâm thời Cộng hòa miền Nam Việt Nam cũng đã tuyên bố lập trường ba điểm về việc giải quyết các vấn đề tranh chấp lãnh thổ. Tiếp đó, Ngày 14 tháng 2 năm 1974, Chính phủ Việt Nam Cộng hòa ra Tuyên cáo khẳng định chủ quyền của Việt Nam đối với hai vùng đảo Hoàng $S a$ và Trường $\mathrm{Sa}$ [26].

Ngày 28/6/1974, đại diện Chính phủ Việt Nam Cộng tại khóa họp thứ nhất Hội nghị Luật biển lần thứ 3 ở Caracas đã ra tuyên bố vùng đảo Hoàng $\mathrm{Sa}$ và vùng đảo Trường $\mathrm{Sa}$ là bộ phận của lãnh thổ Việt Nam. Ngày 5 và 6/5/1975, Chính phủ cách mạng lâm thời Cộng hoà miền Nam Việt Nam thông báo việc giải phóng các đảo ở quần Trường Sa do quân đội Sài Gòn đóng giữ. Chính phủ cách mạng lâm thời Cộng hòa miền Nam Việt Nam tiếp tục khẳng định chủ quyền của Việt Nam đối với hai vùng đảo Hoàng $\mathrm{Sa}$ và Trường $\mathrm{Sa}$.

Mặc dù vùng đảo Hoàng $\mathrm{Sa}$ đã bị Trung Quốc chiếm đóng trái phép bằng vũ lực hoàn toàn từ tháng 1 năm 1974, nhưng Việt Nam vẫn không ngừng phản đối và lên án các hành động xâm chiếm phi pháp này và vẫn thực hiện các hoạt động nhằm thực thi chủ quyền của mình đối với Hoàng $\mathrm{Sa}$ bằng các phương thức hòa bình.
Đầu năm 1974, một thời gian ngắn sau thất bại trong trận chiến chống lại hành động xâm lược của Trung Quốc tại nhóm đảo Lưỡi Liềm thuộc vùng đảo Hoàng $\mathrm{Sa}$, chính quyền Việt Nam Cộng hoà ra quyết định tăng cường lực lượng tại Trường $\mathrm{Sa}$ và chỉ thị quân đội tiến hành chiến dịch Trần Hung Đạo 48 nhằm chiếm một số đảo. Liên tiếp trong các tháng 2 và tháng 3 cùng năm, Việt Nam Cộng hoà tái khẳng định lại chủ quyền của mình đối với hai vùng đảo bằng nhiều con đường như thông qua đại sứ ở Manila, qua hội nghị của Liên Hiệp Quốc về luật biển ở Caracas và hội nghị của Hội đồng Kinh tế Viễn Đông ở Colombia. [21]

Năm 1975: Bộ Ngoại giao Việt Nam Cộng hòa công bố một bạch thư (sách trắng) [27] trình bày những chứng cớ lịch sử và xác định chủ quyền pháp lý của Việt Nam đối với hai vùng đảo Hoàng $\mathrm{Sa}$ và Trường $\mathrm{Sa}$.

Từ ngày 14 đến ngày 28 tháng 4 năm 1975 , các lực lượng hải quân của Mặt trận Dân tộc Giải phóng miền Nam Việt Nam và Việt Nam Dân chủ Cộng hoà đã hoàn toàn thay thế lực lượng Việt Nam Cộng hòa trên năm đảo là Song Tử Tây, Sơn $\mathrm{Ca}$, Nam Yết, Sinh Tồn và Trường Sa.

Tháng 9/1975, Đoàn đại biểu Chính phủ Cách mạng lâm thời Cộng hoà miền Nam Việt Nam tại Hội nghị khí tượng ở Colombo tuyên bố vùng đảo Hoàng $\mathrm{Sa}$ là của Việt Nam và yêu cầu Tổ chức khí tượng thế giới tiếp tục ghi tên trạm khí tượng Hoàng Sa của Việt Nam (trước đây đã được đăng ký trong hệ thống các trạm của $\mathrm{OMM}$ dưới biểu số 48.860) trong danh mục trạm khí tượng của Tồ chức khí tượng thế giới,...

Không chỉ những hoạt động khẳng định và thực thi chủ quyền nêu trên, trong thực tế, các sự kiện, văn kiện, chứng cứ chứng minh chủ quyền của Việt Nam đối với hai vùng đảo Hoàng $\mathrm{Sa}$ và Trường $\mathrm{Sa}$ qua bao thế kỷ đển nay còn rất nhiều. Tuy vậy, với một số dẫn chứng nêu trên, chỉ tính riêng trong giai đoạn từ thế kỷ XVII cho đến giữa năm 1976, khi hai miền thống nhất, ra đời Nước Cộng hòa Xã hội chủ nghĩa Việt Nam, cũng có đủ cơ sở vững chắc để khẳng định chủ quyền của Việt Nam đối với hai 
vùng đảo Hoàng Sa và Trường Sa phù hợp với thực tiễn và pháp luật quốc tế.

Từ những tư liệu lịch sử rõ ràng và căn cứ vào những nguyên tắc của luật pháp và tập quán quốc tế, có thể rút ra các kết luận sau đây:

- Từ lâu, Nhà nước Việt Nam đã khai phá, chiếm hữu thật sự, công khai và liên tục vùng đảo Hoàng $\mathrm{Sa}$ và vùng đảo Trường $\mathrm{Sa}$ khi mà các quần (vùng) đảo này chưa thuộc chủ quyền của bất cứ quốc gia nào. Hoàng $\mathrm{Sa}$ và Trường Sa chưa bao giờ thuộc lãnh thổ của Trung Quốc.

- Suốt trong gần một thế kỷ, nước Pháp đã thực sự đại diện cho Việt Nam trong việc tiếp nối và kế thừa tiến trình lịch sử thực hiện thật sự và liên tục chủ quyền của Việt Nam đối với hai vùng đảo Hoàng $S a$ và Trường $S a$.

- Nhà nước Việt Nam, qua các thời kỳ, kể cả Chính phủ Quốc gia Việt Nam hay Việt Nam Cộng hòa cũng như Chính phủ Việt Nam Dân chủ Cộng hòa và chính phủ Cách mạng lâm thời Cộng hòa Miền Nam Việt Nam, tùy theo các điều kiện và hoàn cảnh, luôn luôn bảo vệ tích cực các quyền và danh nghĩa hợp pháp của mình trước mọi mưu đồ và hành động xâm phạm tới chủ quyền, toàn vẹn lãnh thổ và quyền lợi của Việt Nam đối với hai vùng đảo Hoàng $\mathrm{Sa}$ và Trường $\mathrm{Sa}$.

- Sau khi nước Việt Nam thống nhất, từ năm 1976 cho đến nay, Chính phủ Cộng hoà xã hội chủ nghĩa Việt Nam đã liên tục khẳng định chủ quyền của Việt Nam đối với hai vùng đảo hoàng $\mathrm{Sa}$ và Trường $\mathrm{Sa}$, mặc dù vùng đảo Hoàng $\mathrm{Sa}$ và một phần vùng đảo Trường $\mathrm{Sa}$ đã và đang bị Trung Quốc xâm chiếm phi pháp bằng vũ lực. Việc chiếm đóng của Trung Quốc ở vùng đảo Hoàng $\mathrm{Sa}$ và Trường $\mathrm{Sa}$ của Việt Nam bằng vũ lực là hành vi phạm pháp luật quốc tế nghiêm trọng, là cấu thành tội ác quốc tế, là vô giá trị๋

\footnotetext{
${ }^{5}$ Theo Nghị quyết 26/25 năm 1970 của Liên Hơp Quốc, thì: "Mọi hành động thụ đắc lãnh thổ bằng đe doạ hoặc bằng sử dụng vũ lực là bất hợp pháp". Theo Quy chế Rome về Tòa án Hình sự quốc tế, Điều 5, thì tội xâm lược bị coi là một trong bốn tội phạm nghiêm trọng nhất, là tội ác quốc tế chống lại loài người.
}

\section{Tài liệu tham khảo}

[1] Hiệp ước Patenotre, https://ia802604.us.archive.org/19/items/laffaireduto nkin00dipluoft/laffairedutonkin00dipluoft.pdf

[2] Nguyễn Bá Diến, Yêu sách “đường lưỡi bò” phi lý của Trung Quốc và chủ quyền của Việt Nam trên Biển Đông, Sách chuyên khảo, NXB thông tin và Truyền thông, 2015 , tr. 308-312

[3] http://ict-hcm.gov.vn/tintuc;jsessionid=B6AAE49F8545508B4C9B92B45 2F8564C?chu-quyen-hoang-sa-va-truong-sa-cuaviet-nam-thoi-phapthuoc\&post=MTMg2ODA2OTk1NQ

[4] Chemillier-Gendreau, Monique (2000) (Bản gốc tiếng Pháp 1996], Sovereignty over the Paracel and Spratly Islands (Chủ quyền đối với quần đảo Hoàng $\mathrm{Sa}$ và Trường $\mathrm{Sa}$ ), Springer, ISBN 9789041113818,

[5] Journal Officiel de l'Indochine 25 Septempre 1933, trang 7784.

[6] Chemillier-Gendreau, Monique (2000) [Bản gốc tiếng Pháp 1996], Sovereignty over the Paracel and Spratly Islands [Chủ quyền đối với quần đảo Hoàng $\mathrm{Sa}$ và Trường Sa], Springer, ISBN 9789041113818 , tr. 46

[7] "White Paper on the Hoang Sa (Paracel) and Truong Sa (Spratly) Islands (1975). Ministry of Foreign Affairs (Republic of Vietnam. Truy cập ngày 7/9/2012. Lưu trữ bời WebCite®http://www.webcitation.org/6BiTGZQ B).

[8] Trần Đăng Đại (1975), “Các văn kiện chính thức xác nhận chủ quyền Việt Nam trên hai quần đảo Hoàng $\mathrm{Sa}$ và Trường $\mathrm{Sa}$ từ thời Pháp thuộc tới nay”, Tập san Sử Địa, 29 (Sài Gòn: Nhà in Văn Hữu)

[9] "Quần đảo Trường Sa thuộc tỉnh Bà Rịa (1933)". Trang thông tin điện tử về Biên giới lãnh thổ. Truy cập ngày 15 tháng 8 năm 2012. Lưu trữ bởi WebCite ${ }^{\circledR}$ vào ngày 13 tháng 11 năm 2012 (http://www.webcitation.org/6BiTGZQB)

[10] ${ }^{1}$ https://vi.wikipedia.org/wiki/Quần đảo Trường $\mathrm{Sa}$

[11] Hiệp ước San Francisco, https://treaties.un.org/doc/Publication/UNTS/Volu me\%20136/volume-136-I-1832-English.pdf

[12] Foreign Relations of the United States, Diplomatic Paper: The Conferences at Cairo and Teheran 1943, Washington D.C, United States, G.P.O, 1961, pp. 448-449; Lazar Focsaneanu: "Các hiệp ước hòa bình của Nhật Bản”, Niên giám luật quốc tế của Pháp, 1960, tr. 256. 
[13] Review of International Situation, China Publishing Co, Taipei 1956, pp 22-23.

[14] The Conferences at Cairo and Tehran 1943, The Foreign Relations of the United States, Washington D.C, 1961.

[15] Monique Chemillier- Gendreau, Chủ quyền trên hai quần đảo Hoàng $\mathrm{Sa}$ và Trường $\mathrm{Sa}, \mathrm{NXB}$. Chính trị Quốc gia, Hà Nội-1998, tr.136.

[16] Công văn N 5454 của Cao ủy Pháp tại Đông Dương gửi Paris, ngày 3.6.1946. Lưu trữ Bộ Ngoại giao Pháp, AO 44 - 45, Hồ sơ 214 ( Tiếng Pháp), tr.1.

[17] J.P. Ferrier, “Tranh chấp các đảo Hoàng Sa và vấn đề chủ quyền trên các đảo không người ở" ( Tiếng Pháp). Niên giám của Pháp về luật quốc tế, 1975, tr.191

[18] Heinzig Dieter, Các đảo tranh chấp trên biển Nam Trung Hoa,Wesbaden, Otto Harrassowith và Viện các vấn đề châu Á ở Hamburg, 1976, tr.35.

[19] Nguyễn Quang Ngọc, Chủ quyền của Việt Nam ở Hoàng $\mathrm{Sa}$, Trường Sa tư liệu và sự thật lịch sử, NXB Đại học Quốc gia Hà Nội, 2017, tr. 299

[20] https://vi.wikipedia.org/wiki/Quần đảo Trường $\mathrm{Sa}$

[21] Nguyễn, Nhã (2002), Quá trình xác lập chủ quyền của Việt Nam tại quần đảo Hoàng $\mathrm{Sa}$ và Trường Sa (Luận án tiến sĩ), Trường Đại học Khoa học Xã hội và Nhân văn (Đại học Quốc gia Thành phố Hồ Chí Minh), tr. 109

[22] Conference for the Conclusion and Signature of the Peace Treaty with Japan, U. N. Treaty Series, Volume 136, p. 46.
[23] Decree no.174-NV from the presidency of Ngô Đình Diệm, Republic of Vietnam (VNCH), redistricting the Paracel Islands as part of Quảng Nam Province effective 07-13-1961. Paracels were previously part of Thừa Thiên (Huế) Province since 03-30-1938, when redistricted by the government of French Indochina. Decree dated 07-13-61.

[24] "Một số văn kiện xác nhận chủ quyền của Việt Nam trên hai quần đảo Hoàng Sa và Trường Sa từ thời Pháp thuộc đến trước 30/4/1975 - Kì 3”. Cục Thông tin Đối ngoại (Việt Nam), 16 tháng 4 năm 2012. Truy cập ngày 31 tháng 10 năm 2012. Lưu trữ bởi $\quad$ WebCite ${ }^{\circledR}$ tại http://www.webcitation.org/6BiTGZQB.

[25] Tuyên cáo của Bộ Ngoại Giao Việt Nam Cộng hòa về hành động gây hấn của Trung Cộng (19.1.1974)

http://www.nguyenthaihocfoundation.org/lichsuV N/tuyenbo_vnch.htm

[26] Tuyên bố của Chính phủ Việt Nam Cộng Hòa ngày 14 tháng 02 năm 1974). Nguồn: http://www.nguyenthaihocfoundation.org/lichsu VN/tuyenbo_vnch.htm

[27] White Paper on the Hoang Sa (Paracel) and Truong Sa (Spratly) Islands, Republic of Vietnam, Ministry of Foreign Affairs, Saigon, 1975, http://nguyenthaihocfoundation.org/lichsuVN/hsts 1.htm. 